\title{
Effect of Different Levels of Nitrogen, Phosphorous and Potassium on Growth, Yield Attributes and Yield of Indian Mustard (Brassica juncea (L.) Czern and Coss) in S-E Rajasthan
}

\author{
Adarsh Sharma $^{1 *}$, B. S. Meena ${ }^{1}$, R. K Meena ${ }^{1}$, R. K Yadav', \\ B. K. Patidar ${ }^{3}$ and Ramesh Kumar \\ ${ }^{1}$ Department of Agronomy, ${ }^{2}$ Department of Soil Science and Agricultural Chemistry, \\ ${ }^{3}$ Department of Entomology, ${ }^{4}$ Department of Genetics and Plant Breeding, College of \\ Agriculture, Ummedganj, Kota, Rajasthan-324001, India \\ *Corresponding author
}

\begin{tabular}{l} 
K e y w o r d s \\
Indian mustard, \\
$\begin{array}{l}\text { Nutrient } \\
\text { management, Seed } \\
\text { yield, Stover yield }\end{array}$ \\
Article Info \\
$\begin{array}{l}\text { Accepted: } \\
17 \text { August } 2020 \\
\text { Available Online: } \\
\text { 10 September } 2020\end{array}$ \\
\hline
\end{tabular}

\section{A B S T R A C T}

\section{Introduction}

Importance of oilseed in agriculture needs further attention, as they are valuable items of human nutrition and soil fertility. In India, rapeseed-mustard is grown over 5.96 million ha area with a production of 8.32 million tonnes at an average productivity of 1397 
$\mathrm{kg} / \mathrm{ha}$ (GOI, 2017-18). It is the most important rabi season oilseed crop of Rajasthan which is grown on $2.38 \mathrm{mha}$ with annual production of $3.95 \mathrm{mt}$ at an average productivity of 1656 kg/ha (Anonymous, 2019-20). The optimum sowing time of Indian mustard in southeastern Presently in south-eastern Rajasthan Indian mustard (Brassica juncea) is being grown on vertisols under irrigated conditions after harvest of urdbean /soybean without considering nutrient management which is essential for harvesting good yield.

Imbalanced use of chemical fertilizers especially N,P\&K not only lowers productivity but also adversely affects soil health by continuous. Decline in crop yield due to lack of $\mathrm{K}$ supply was reported even in $\mathrm{K}$ rich soils like Vertisols (Singh and Wanjari, 2012). Furthermore, the inadequate supply of $\mathrm{K}$ also limits the responses to applied $\mathrm{N}$ and $\mathrm{P}$ fertilizer. Nitrogen deficiency may decrease yield while, excess $\mathrm{N}$ availability reduces the oil quality. Under the present situation application of major nutrient elements NP\&K is essential for increasing mustard yield and maintaining crop production at higher level in irrigated condition.

Considering these facts, the present study was therefore, undertaken to evaluate the effect of major nutrient $\mathrm{N}, \mathrm{P} \& \mathrm{~K}$ management for Indian mustard grown on Vertisol after harvest of urdbean in irrigated areas of south east Rajasthan.

\section{Materials and Methods}

A field experiment was conducted at Agriculture Research Station, Kota $\left(26^{\circ}\right.$ North latitude, 76 -6 ' East longitude and $260 \mathrm{~m}$ above mean sea level) during the rabi seasons of 2019-20 to study the effect of different levels of nitrogen, phosphorous and potassium nutrient management on growth, yield attributes, yield, quality and economics of Indian mustard grown after harvest of urdbean invertisols of south-east Rajasthan under irrigated condition. The experimental soil was clay loam in texture with a $\mathrm{pH}$ of 7.95 , medium in organic carbon $(0.54 \%)$, available nitrogen $(280 \mathrm{~kg} / \mathrm{ha})$, phosphorus (40.3 kg/ha) and high in potassium (400 $\mathrm{kg} / \mathrm{ha})$, zinc $(0.92 \mathrm{mg} / \mathrm{kg}$ soil) and low in sulphur $(8.85 \mathrm{~kg} / \mathrm{ha})$ contents. The experiment comprised of 18 treatments with three levels of nitrogen viz., 80, 100 and $120 \mathrm{~kg} / \mathrm{ha}$, two levels of phosphorous fertilizer viz., 40 and 50 $\mathrm{kg} / \mathrm{ha}$ in main plots, and three levels of potassium fertilizer viz., 15, 30 and $45 \mathrm{~kg} / \mathrm{ha}$ in sub plots were assigned in sub-sub plots and laid out in split-plot design with 3 replication.

Uniform application of FYM with treatment doses of NP\&K were supplied through urea, dia-ammonium phosphate, muriate of potash, respectively. Full dose of $\mathrm{P}_{2} \mathrm{O}_{5}, \mathrm{~K}_{2} \mathrm{O}$ and halfN were applied as basal at planting and half dose of $\mathrm{N}$ was top-dressed at 40 days after planting of the crop as per treatments. 5 $\mathrm{kg} / \mathrm{ha}$ seed of variety 'DRMRIJ 31' was used. The gross plot size for each treatment was 6 $\mathrm{m} \times 3.6 \mathrm{~m}$ and net plot size was $5 \mathrm{~m} \times 2.7 \mathrm{~m}$. All the recommended agronomic practices were done throughout the crop season. The average annual rainfalls received during cropping period of one year were $190 \mathrm{~mm}$. The crop was harvested manually at physiological maturity stage as per treatments. Initial and post-harvest soil samples were collected from $0-15 \mathrm{~cm}$ depth, dried processed and analyzed for oxidizable organic carbon, N, P, K and S using standard procedures. Growth, yield attributes, seed yield, quality parameter and nutrient uptake were workout as per standard statistical procedure and using formulae. Gross and net returns were calculated based on the seed and straw yield and prevailing market prices of mustard in respective seasons. The benefit: cost ratio was calculated by dividing the net 
returns from the total cost of cultivation. The data were statistically analyzed and the results of pooled analysis are presented.

\section{Results and Discussion}

\section{Effect of Nitrogen}

Growth and yield attributes of Indian mustard were significantly influenced due to application of graded levels of Nitrogen fertilization contributed to a great extent in influencing the seed yield of mustard on account of its pronounced effect on the growth and yield attributes of the plant, at various stages of the crop growth. Application of $120 \mathrm{~kg} \mathrm{~N} / \mathrm{ha}$ registered higher growth and yield attributing characters (Table 1)vizon plant height $(224.5 \mathrm{~cm})$, dry matter/meter row length (346.8 g), primary and secondary branches/plant (5.82 and 15.02), siliquae/plant (213.8), seeds/siliqua (15.94), length of siliqua $(5.53 \mathrm{~cm}), 1000$-seed weight $(5.30 \mathrm{~g})$. However there was no statistical difference between 100 and $120 \mathrm{~kg} \mathrm{~N} / \mathrm{ha}$.

These growth and yield parameters increased significantly with increasing levels of nitrogen upto $100 \mathrm{~kg} \mathrm{~N} / \mathrm{ha}$. Probably $120 \mathrm{~kg}$ $\mathrm{N} /$ ha ensured the availability of other nutrient and favourable condition for growth of mustard plant. Nitrogen increase in size of cell, which expressed morphologically increased in plant height, leaf area and branches/plant.

Nitrogen provide deep green colour to leaves due to better chlorophyll synthesis which increase the effective area of photosynthesis and resulting in higher dry matter. These results are in conformity with finding of Singh and Kumar, (2014)

The application of $100 \mathrm{~kg}$ produced significantly higher (Table 2) seed yield and stover yield as compared to $80 \mathrm{~kg} \mathrm{~N} / \mathrm{ha}$ however, it was found at pat with $120 \mathrm{~kg}$ $\mathrm{N} /$ ha. The maximum seed and stover yield were recorded with the application of $120 \mathrm{~kg}$ $\mathrm{N} / \mathrm{ha}$. The increase in yield of mustard due to nitrogen application may be because of the fact that nitrogen played an important role in synthesis of chlorophyll and amino acids, which constitute building of protein blocks.

Nitrogen influenced the seed yield through a source-sink relationship and in addition to higher production of photosynthates it leads to increased translocation to reproductive parts. Nitrogen being a most important plant nutrient needed for growth and development of plant and is known to increase the yield of Brassica species (Singh et al., 2002).

\section{Effects of phosphorous}

Application of $50 \mathrm{~kg} \quad \mathrm{P}_{2} \mathrm{O}_{5} / \mathrm{ha}$ recorded significantly the highest plant height at 60 and 90 DAS (Table 1) (91.6 and $191.1 \mathrm{~cm}$ ) except at harvest, dry matter accumulation at all growth stages, primary and secondary branches/plant (5.45 and 14.66) siliquae/plant (204.3), seeds/siliqua (15.94), length of siliqua $(5.43 \mathrm{~cm}), 1000$-seed weight $(5.19 \mathrm{~g})$.

The seed yield (Table 2) (2830 kg/ha) and stover yield $(6929 \mathrm{~kg} / \mathrm{ha})$ of mustard increased significantly due to application of $50 \mathrm{~kg} \mathrm{P}_{2} \mathrm{O}_{5} / \mathrm{ha}$ over its lower level of phosphorus. The per cent increase in seed yield 8.22 was with $50 \mathrm{~kg} \mathrm{P}_{2} \mathrm{O}_{5} /$ ha level of phosphorus over $40 \mathrm{~kg} \mathrm{P}_{2} \mathrm{O}_{5} /$ ha level whereas the corresponding value for increase in stover yield was 4.50 per cent.

The supply of phosphorus to plant might have accelerated cell division and enlargement, carbohydrate, fat metabolism and respiration in plant. These results are in agreement with the findings of Rana et al., (2005) in mustard; Sune et al., (2006) in linseed; and Dhage et al., (2014) in soybean. 
Table.1 Effect of nitrogen, phosphorous and potassium on plant height and dry matter accumulation at 60, 90 DAS and at harvest of Indian mustard

\begin{tabular}{|c|c|c|c|c|c|c|c|c|}
\hline \multirow{2}{*}{$\begin{array}{l}\text { Treatments } \\
\text { Nitrogen } \\
\text { (kg/ha) }\end{array}$} & \multicolumn{2}{|c|}{ At 60 DAS } & \multicolumn{2}{|c|}{ At 90 DAS } & \multicolumn{4}{|c|}{ At harvest } \\
\hline & $\begin{array}{l}\text { Plant height } \\
\text { (cm) }\end{array}$ & $\begin{array}{l}\text { Dry matter/ m } \\
\text { row length }\end{array}$ & $\begin{array}{l}\text { Plant height } \\
\text { (cm) }\end{array}$ & $\begin{array}{l}\text { Dry matter/ } \\
\text { row length }\end{array}$ & $\begin{array}{l}\text { Plant height } \\
\text { (cm) }\end{array}$ & $\begin{array}{l}\text { Dry matter/ m } \\
\text { row length }\end{array}$ & $\begin{array}{l}\text { Primary } \\
\text { Branches/plant }\end{array}$ & $\begin{array}{l}\text { Secondary } \\
\text { Branches/plant }\end{array}$ \\
\hline 80 & 79.0 & 136.5 & 169.7 & 226.0 & 193.1 & 295.4 & 4.38 & 12.28 \\
\hline 100 & 87.5 & 153.6 & 188.4 & 252.1 & 202.4 & 332.5 & 5.24 & 14.42 \\
\hline 120 & 99.8 & 155.7 & 196.8 & 259.6 & 224.5 & 346.8 & 5.82 & 15.02 \\
\hline $\mathrm{SEm} \pm$ & 0.67 & 3.50 & 3.08 & 1.16 & 2.65 & 5.53 & 0.18 & 0.43 \\
\hline $\mathrm{CD}(\mathrm{P}=\mathbf{0 . 0 5})$ & 2.62 & 13.74 & 12.09 & 4.54 & 10.41 & 21.72 & 0.72 & 1.67 \\
\hline \multicolumn{9}{|l|}{$\begin{array}{l}\text { Phosphorous } \\
\text { (kg/ha) }\end{array}$} \\
\hline 40 & 85.9 & 144.6 & 178.82 & 241.1 & 206.0 & 320.09 & 4.84 & 13.15 \\
\hline 50 & 91.6 & 152.5 & 191.19 & 250.4 & 207.3 & 329.64 & 5.45 & 14.66 \\
\hline $\operatorname{SEm} \pm$ & 1.63 & 2.21 & 3.33 & 2.21 & 1.49 & 2.48 & 0.06 & 0.22 \\
\hline $\mathrm{CD}(\mathrm{P}=0.05)$ & 5.62 & 7.63 & 11.51 & 7.66 & NS & 8.59 & 0.22 & 0.75 \\
\hline \multicolumn{9}{|l|}{$\begin{array}{l}\text { Potassium } \\
\text { (kg/ha) }\end{array}$} \\
\hline 15 & 84.7 & 145.00 & 181.7 & 239.0 & 201.7 & 317.3 & 4.83 & 13.43 \\
\hline 30 & 88.9 & 150.22 & 183.7 & 246.5 & 208.0 & 323.1 & 5.15 & 13.99 \\
\hline 45 & 92.7 & 150.59 & 189.7 & 252.1 & 210.2 & 334.2 & 5.46 & 14.29 \\
\hline $\mathrm{SEm} \pm$ & 1.12 & 3.08 & 2.33 & 2.58 & 1.93 & 4.49 & 0.13 & 0.25 \\
\hline $\mathrm{CD}(\mathrm{P}=0.05)$ & 3.28 & NS & NS & 7.54 & 5.63 & 13.09 & 0.39 & NS \\
\hline
\end{tabular}


Table.2 Effect of nitrogen, phosphorous and potassium on silique/plant, seeds/plant, siliqua length, 1000-seed weight, seed and stover yield, of India mustad

\begin{tabular}{|c|c|c|c|c|c|c|}
\hline Treatment & $\begin{array}{l}\text { Siliquae/ } \\
\text { plant }\end{array}$ & $\begin{array}{l}\text { Seeds/ } \\
\text { siliqua }\end{array}$ & $\begin{array}{c}\text { Siliqua } \\
\text { length } \\
\text { (cm) }\end{array}$ & $\begin{array}{l}1000 \text { seed } \\
\text { weight }(\mathrm{g})\end{array}$ & $\begin{array}{c}\text { Seed yield } \\
\text { (kg/ha) }\end{array}$ & $\begin{array}{c}\text { Stover Yield } \\
\text { (Kg/ha) }\end{array}$ \\
\hline \multicolumn{7}{|l|}{ Nitrogen (kg/ha) } \\
\hline 80 & 173.3 & 14.88 & 5.04 & 4.70 & 2544 & 6433 \\
\hline 100 & 201.3 & 15.71 & 5.33 & 5.12 & 2764 & 7009 \\
\hline 120 & 213.8 & 15.94 & 5.53 & 5.30 & 2861 & 7016 \\
\hline SEm \pm & 7.31 & 0.19 & 0.07 & 0.10 & 40.45 & 51.27 \\
\hline $\mathrm{CD}(\mathrm{P}=\mathbf{0 . 0 5})$ & 28.69 & 0.73 & 0.29 & 0.40 & 158.80 & 201.27 \\
\hline CV $(\%)$ & 15.81 & 5.11 & 5.93 & 8.64 & 6.30 & 3.19 \\
\hline \multicolumn{7}{|c|}{ Phosphorus (kg/ha) } \\
\hline 40 & 187.9 & 15.08 & 5.18 & 4.93 & 2615 & 6710 \\
\hline 50 & 204.3 & 15.94 & 5.43 & 5.19 & 2830 & 6929 \\
\hline SEm \pm & 1.78 & 0.22 & 0.06 & 0.03 & 51.97 & 18.81 \\
\hline $\mathrm{CD}(\mathrm{P}=\mathbf{0 . 0 5})$ & 6.15 & 0.76 & 0.22 & 0.12 & 179.81 & 65.09 \\
\hline CV (\%) & 4.71 & 7.36 & 6.31 & 3.42 & 9.92 & 1.43 \\
\hline \multicolumn{7}{|l|}{ Potassium (kg/ha) } \\
\hline 15 & 187.2 & 14.94 & 5.11 & 4.85 & 2557 & 6634 \\
\hline 30 & 197.9 & 15.56 & 5.36 & 5.16 & 2756 & 6774 \\
\hline 45 & 203.2 & 16.03 & 5.46 & 5.17 & 2856 & 7050 \\
\hline SEm \pm & 4.31 & 0.25 & 0.05 & 0.07 & 57.50 & 50.23 \\
\hline $\mathrm{CD}(\mathrm{P}=\mathbf{0 . 0 5})$ & 12.58 & 0.74 & 0.14 & 0.21 & 167.82 & 146.58 \\
\hline CV $(\%)$ & 9.33 & 6.89 & 3.79 & 6.04 & 8.96 & 3.12 \\
\hline
\end{tabular}

\section{Effect of Potassium}

Among potassium levels, application of $30 \mathrm{~kg}$ $\mathrm{K}_{2} \mathrm{O} / \mathrm{ha}$ was found significantly superior with respect to plant height at 60 DAS (Table 1), dry matter accumulation per meter row length at harvest, primary branches/plant, number of siliquae/plant (197.3), seeds/siliqua (15.56), length of siliqua $(5.46 \mathrm{~cm}), 1000$-seed weight $(5.17 \mathrm{~g})$, seed yield $(2756 \mathrm{~kg} / \mathrm{ha})$, biological yield $(9877 \mathrm{~kg} / \mathrm{ha})$ and found at par with 45 $\mathrm{kg} \mathrm{K}_{2} \mathrm{O} / \mathrm{ha}$ (Table 2). Whereas, secondary branches/plant and stover yield could not influenced significant by potassium levels. The maximum number siliquae/plant and number of seeds/siliqua in case of $60 \mathrm{~kg}$ $\mathrm{K}_{2} \mathrm{O} / \mathrm{ha}$ which could be attributed to favourable soil environments like better availability as well as absorption of water and nutrients due to balanced application of potassium that promoted vegetative and reproductive growth processes of the crop The increase in oil content confirmed the findings of Misras (2003) in mustard.

\section{References}

Anonymous, 2019-20.Rajasthan Agricultural Statistics at a glance, Commissione rate of Agriculture, Jaipur, Rajasthan, pp.88.

Dhage Shubhangi J, Patil V.D, Patange Mamta J. 2014. Effect of various levels of phosphorus and sulphur on yield, plant nutrient content, uptake and availability of nutrients at harvest stages of soybean [Glycine $\max (\mathrm{L})$.$] .$ 
International Journal of Current Microbiology and Applied Science. 3(12): 833-844.

GOI Statistics. 2017-18. Directorate of Economics and Statistics, DAC and FW, pp.110-112.

Misras K., 2003. Effect of S and K on yield, nutrient uptake and quality characteristics of mustard (Brassica juncea L.) in Kanpur. Journal of Indian Society of Soil Science, 51: 544-548.

Rana K.S, Rana D.S, Gautam R.C. 2005. Influence of phosphorus, sulphur and boron on growth, yield, nutrient uptake and economics of Indian mustard (Brassica juncea) under rainfed conditions. Indian Journal of Agronomy, 50(4): 314-316.

Singh A.K, Prasad S.M, Singh S.B. 2002. Effect of nitrogen levels and varieties on production potential of yellow sarson (Brassica campestris L. var. yellow sarson). Indian Journal of Agronomy 47(1):105-108.

Singh, M. and Wanjari, R. H. 2012. All India Coordinated Research Project on Long Term Fertilizer Experiments to study changes in soil quality, crop productivity and sustainability. AICRPLTFE. Indian Institute of Soil Science, Bhopal. Annual Report-2010-11, pp. 1114.

Singh M., Kumar M. 2014. Effect of nitrogen and sulphur levels on seed yield and some other characters in mustard [Brassica juncea (L.) Czern and Coss]. International Journal of Agriculture Sciences. 10(1):449-452.

Sune S.V, Deshpande R.M, Khawale V.S, Baviskar P.K, Gurao B.P. 2006. Effect of phosphorus and sulphur application on growth and yield of linseed. Journal of Soils and Crops, 16(1): 217-221.

\section{How to cite this article:}

Adarsh Sharma, B. S. Meena, R. K Meena, R. K Yadav, B. K. Patidar and Ramesh Kumar. 2020. Effect of Different Levels of Nitrogen, Phosphorous and Potassium on Growth, Yield Attributes and Yield of Indian Mustard (Brassica juncea (L.) Czern and Coss) in S-E Rajasthan. Int.J.Curr.Microbiol.App.Sci. 9(09): 2216-2221. doi: https://doi.org/10.20546/ijcmas.2020.909.276 